\title{
DETERMINATION OF TOTAL AND NON-CARBONATE CARBON IN ROCK SAMPLES BY A METHOD USING INFRARED ABSORPTION
}

\author{
RISTO J. SAIKKONEN and IRJA A. RAUTIAINEN
}

\begin{abstract}
SAIKKONEN RISTO J. and RAUTIAINEN, IRJA A., 1990: Determination of total and non-carbonate carbon in rock samples by a method using infrared absorption. Bull. Geol. Soc. Finland 62, Part 2, 149-156.

Total and non-carbonate carbon were determined by a method using infrared absorption in 20 international geological reference samples, 13 in-house reference samples and 13 other rock samples. For the determination of total carbon, $\mathrm{C}_{\mathrm{TOT}}$, the samples were combusted at $1370^{\circ} \mathrm{C}$ in oxygen flow. Non-carbonate carbon, $\mathrm{C}_{\text {NONC }}$, was determined in a similar way but the samples were leached with hydrochloric acid to remove carbonate carbon before combusting. The concentration of carbonate carbon, $\mathrm{CO}_{2}$, was calculated from the difference $\mathrm{C}_{\mathrm{TOT}}-\mathrm{C}_{\mathrm{NONC}}$.

The results $\left(\mathrm{C}_{\mathrm{TOT}}, \mathrm{C}_{\mathrm{NONC}}\right.$ and calculated $\left.\mathrm{CO}_{2}\right)$ for the 20 international geological reference samples compared well with published data. The results $\left(\mathrm{C}_{\mathrm{TOT}}, \mathrm{C}_{\mathrm{NONC}}\right.$ and calculated $\mathrm{CO}_{2}$ ) for the 13 in-house reference and 13 other rock samples agreed well with the results obtained by gravimetric methods. The precision of the used method was good: relative standard deviation was about $1 \%, 5 \%$ and $10 \%$ when the carbon content of the sample was $10 \%, 1 \%$ and $0.1 \%$ respectively. The effective detection limit was $0.01-0.02 \% \mathrm{C}$.

Key words: chemical analysis, methods, infrared spectroscopy, carbon, rocks.
\end{abstract}

Risto J. Saikkonen and Irja A. Rautiainen: Geological Survey of Finland. SF-02150 Espoo, Finland.

\section{Introduction}

Carbon is very widely distributed in rock samples ranging all the way from per cent level to ppm level. Although it is usually present in the form of carbonates such as calcite, dolomite and siderite, it may also occur as graphite or even carbide. In the form of graphite or carbonaceous matter (a mixture of graphite and organic matter), carbon is usually present only in small amount, although it may reach a concentration of several per cent in graphite schists and slates (Hillebrand 1953). Carbon is an essential constituent in many minerals as carbonate carbon or elementary carbon. In addition to these there are a few minerals with $\mathrm{CO}$ and $\mathrm{CN}$ groups (Wedepohl 1968). Carbon also occurs in the form of carbon dioxide, methane and hydrocarbons in fluid inclusions, according to Raman spectroscopic and freezing stage observations. These fluid inclusions are common in metamorphic rocks (Roedder 1984).

Carbon is usually determined in rock analysis either as carbonate carbon or as total carbon, which besides carbonate carbon includes noncarbonate carbon, (graphite and carbon present in organic matter). Most analytical methods for determining carbon in rock samples are based on the formation and liberation of $\mathrm{CO}_{2}$ by acid decomposition, thermal decomposition or wet 
oxidation (Potts 1987, Johnson and Maxwell 1981), and determination of the $\mathrm{CO}_{2}$ usually by gravimetric (Maxwell 1968), volumetric (Betelev and Kudachkin 1988), titrimetric (Riddle and Talerico 1978), coulometric (Chan 1986, Engleman and al. 1985), thermal conductimetric (Schofield and al.1980) or infrared absorption spectrometric (Terashima 1988, Bouvier and Abbey 1980). The carbonate and non-carbonate carbon can be differentiated by applying acid digestion to remove the carbonate carbon, or by thermodecomposition at temperatures specific for the two types of carbon (Charles and Simmons 1986, Krom and Berner 1983, Leventhal and Shaw 1980).

In this study the CR-12 carbon analyzer (Leco Corporation) of the Geological Survey of Finland was used to determine the content of total carbon $\left(\mathrm{C}_{\mathrm{TOT}}\right)$ and non-carbonate carbon $\left(\mathrm{C}_{\mathrm{NONC}}\right)$ in 20 international geological reference samples, 13 in-house reference samples and 13 other rock samples. The CR-12 carbon analyzer has been used earlier to determine total carbon in geological samples (Johnson and Maxwell 1981, Krom and Berner 1983), but our method for determination of non-carbonate carbon after leaching with hydrochloric acid has not been published earlier. The results for calculated carbon dioxide, $\left[\mathrm{CO}_{2}=\left(\mathrm{C}_{\mathrm{TOT}}-\mathrm{C}_{\mathrm{NONC}}\right)^{* 3.6641}\right]$, in the inhouse and other rock samples were compared with the results obtained by the classical acid evolution - gravimetric method. And the results for $\mathrm{C}_{\mathrm{NONC}}$ in the 13 other rock samples were compared with results obtained by the gravimetric method. In the case of the international geological reference samples, the results for $\mathrm{C}_{\text {Tот }}$, $\mathrm{C}_{\mathrm{NONC}}$ and calculated $\mathrm{CO}_{2}$ were compared with published data.

\section{Experiment}

\section{Apparatus}

The CR-12 (model 781-600) is a microprocessor-controlled instrument for determining carbon in rock samples as well as in a variety of other materials. The system consists of a measurement unit (model 781-700) and a control console (model 780-00). Ceramic combustion boats (model 529-203) are used to hold the samples. Anhydrous magnesium perchlorate is used in the drying tubes. ( $\mathrm{F}, \mathrm{Cl}$ absorbent is used for the determination of the non-carbonate carbon). The recommended carrier gas is $99.5 \%$ pure oxygen.

For the measurement of the carbon, the sample is combusted at $1370^{\circ} \mathrm{C}$ in an oxygen atmosphere, where the carbon oxidizes to carbon dioxide. Moisture and dust are removed by two drying tubes and a filter. The carbon dioxide driven with oxygen carrier gas passes through the infrared (IR) cell, where the carbon dioxide absorbs energy at a specific wavelength within the IR spectrum. This wavelength is selectively passed through a filter to an IR sensor, where the concentration of carbon dioxide is detected as an energy level. The energy level is amplified, rectified and converted to a digital signal. The microprocessor formulates the analytical results by combining the outputs of the infrared detector and system ambient sensors with preprogrammed calibration, linearization and weight compensation factors and displays the results on the control console. The printer prints out the results, together with the time and date, I.D. code (the identification of a sample), the calibration number and the carbon as weight per cent.

\section{Procedure}

The CR-12 instrument was operated as specified in the manufacturer's manual and calibrated with calcium carbonate (reagent grade, commercial). The calibration was checked with inhouse reference samples or international reference samples. Briefly the procedure for total carbon determination was as follows: About $0.5-1.0 \mathrm{~g}$ (depending on the carbon content) of the powdered rock sample was accurately 
weighed into a ceramic combustion boat, with the powder spread evenly over the bottom of the boat. The boat was then slid into the furnace (temperature $1370^{\circ} \mathrm{C}$ ) using the boat puller. The carbon dioxide was driven off and passed with oxygen carrier gas through the IR cell. The result was displayed as weight per cent.

The procedure for the non-carbonate carbon determination was as follows: $0.5-1.0 \mathrm{~g}$ (depending on the carbon content) of the powdered rock sample was accurately weighed into a ceramic combustion boat. The sample was moistened with water and about $4 \mathrm{ml} \mathrm{HCl}(6 \mathrm{M})$ was carefully added to the boat to remove the carbonate carbon. The sample was evaporated to dryness on a sand bath at about $120^{\circ} \mathrm{C}$. The $\mathrm{HCl}$ treatment was repeated twice, after which the sample was washed with water ten times to remove all remaining acid. The boats were dried in an oven at $100^{\circ} \mathrm{C}$ overnight. The non-carbonate carbon was then determined in the same manner as the total carbon.

The drying tubes usually need to be changed after the determination of about 50 samples. The blank determination was made by analyzing pure quartz in the same manner as the sample.

\section{Gravimetric methods}

Carbonate carbon was determined by the classical, acid evolution -gravimetric method (Volborth 1969). The method was as follows: $1.0-5.0 \mathrm{~g}$ of powdered sample was accurately weighed and transferred to the reaction vessel fitted with a condenser. The carbon dioxide was liberated from the sample using hot hydrochloric acid, purified of unwanted volatile constituents by passage through absorbing media and finally collected in the soda - asbestos absorption tube for the gravimetric determination. Air freed of $\mathrm{CO}_{2}$ was used as carrier gas.

Non-carbonate carbon was determined by gravimetric method in which carbonate carbon was boiled out with mineral acids and the noncarbonate carbon was filtered and weighed. The procedure was as follows: $0.5-1.0 \mathrm{~g}$ of powdered sample was accurately weighed in a $100 \mathrm{ml}$ platinum dish, $5 \mathrm{ml}$ of distilled water and $5 \mathrm{ml}$ of concentrated nitric acid were added. After heating of the mixture below the boiling point on a hot plate for 10 minutes, $20 \mathrm{ml}$ of hydrofluoric acid was added and heating was continued until the inorganic matter, except non-carbonate carbon, was decomposed. Then the solution was evaporated to fumes of nitric acid. Concentrated nitric acid $(10 \mathrm{ml})$ and $40 \mathrm{ml}$ of distilled water were added and the solution was warmed. The hot solution was poured into a quartz filtering crucible. The crucible and the washed residue were dried at $110^{\circ} \mathrm{C}$ for two hours and weighed. The non-carbonate carbon was burned away in a furnace at $1100^{\circ} \mathrm{C}$, after which the crucible was weighed again. The loss in weight was the noncarbonate carbon.

\section{Results}

\section{Precision and accuracy}

The precision of the used method was evaluated from the results of 2 to 43 re-determinations of the international and in-house reference rock samples (Tables 1-7). The relative standard deviation was about $1 \%, 5 \%$ or $10 \%$ when the carbon content of the sample was $10 \%, 1 \%$ or $0.1 \%$, respectively. The precision of the used method was good, following well the general trend of small values of the relative deviation for samples with high concentrations of constituents and large values for samples with low concentrations.

The used method gave good results (total carbon, $\mathrm{C}_{\mathrm{TOT}}$, non-carbonate carbon, $\mathrm{C}_{\mathrm{NONC}}$, and calculated carbon dioxide, $\mathrm{CO}_{2}$,) for 20 international geological reference samples relative to published values (Tables $1-3$ ). The results for the calculated carbon dioxide $\left[\mathrm{CO}_{2}=\left(\mathrm{C}_{\mathrm{TOT}}-\right.\right.$ $\left.\mathrm{C}_{\mathrm{NONC}}\right) * 3.6641$ ], in 13 in-house reference rock samples, agreed well with the results obtained by the acid evolution - gravimetric method (Tables 
Table 1. Total carbon, $\mathrm{C}_{\mathrm{TOT}}$, in 20 international geological reference samples. $\mathrm{C}_{\mathrm{TOT}}$ determined by infrared absorption method. $\mathrm{SD}=$ standard deviation. $\mathrm{N}=$ number of determinations.

\begin{tabular}{|c|c|c|c|c|}
\hline Sample & & $\begin{array}{c}\text { Mean }+-\mathrm{SD} \\
\% \mathrm{C}_{\mathrm{TOT}}\end{array}$ & $\mathrm{N}$ & $\begin{array}{c}\text { Literature } \\
\text { values } \\
\% \mathrm{C}_{\mathrm{TOT}} \\
\end{array}$ \\
\hline G-2 & Granite & 0.03 & 1 & $0.02(\mathrm{G})$ \\
\hline NBS-278 & Obsidian Rock & $0.03+-0.00$ & 2 & 0.05 (A) \\
\hline GXR-4 & Copper Mill head & $0.05+-0.01$ & 3 & $0.07(\mathrm{G})$ \\
\hline PCC-1 & Peridotite & 0.06 & 1 & $0.04(\mathrm{G})$ \\
\hline SG-1A & Albities granite & $0.06+-0.01$ & 2 & $0.06(\mathrm{~A})$ \\
\hline SGD-1A & Gabbro & $0.07+-0.01$ & 2 & $0.06(\mathrm{~A})$ \\
\hline ST-1A & Trap & $0.09+-0.01$ & 2 & $0.06(\mathrm{~A})$ \\
\hline SY-3 & Syenite & $0.13+-0.01$ & $7 *$ & $0.13(\mathrm{~A})$ \\
\hline GXR-1 & Jasperoid & $0.14+-0.01$ & 3 & $0.16(\mathrm{G})$ \\
\hline SY-2 & Syenite & $0.16+-0.02$ & $5^{*}$ & $0.15(\mathrm{~A})$ \\
\hline GXR-6 & Soil & $0.17+-0.00$ & 3 & $0.15(\mathrm{G})$ \\
\hline MRG-1 & Gabbro & $0.32+-0.02$ & $10 *$ & $0.30(\mathrm{~A})$ \\
\hline SCo-1 & Cody Shale & $0.97+-0.05$ & $7 *$ & 0.99 (A) \\
\hline \multirow[t]{2}{*}{ GXR-3 } & Fe-Mn-W-rich & & & \\
\hline & Hot Spring Deposit & $1.26+-0.01$ & $6^{*}$ & $1.31(\mathrm{G})$ \\
\hline ES $681-1$ & Iron Ore & $1.69+-0.07$ & $7 *$ & $1.80(\mathrm{~A})$ \\
\hline GXR-5 & Soil & $1.85+-0.01$ & $6^{*}$ & $1.68(\mathrm{G})$ \\
\hline MAG-1 & Marine Mud & $2.23+-0.02$ & 3 & $2.15(\mathrm{G})$ \\
\hline GXR-2 & Soil & $2.79+-0.01$ & $6^{*}$ & $2.61(\mathrm{G})$ \\
\hline SDO-1 & Devonian Ohio Shale & $9.97+-0.08$ & $7^{*}$ & $9.95(\mathrm{G})$ \\
\hline NBS-88a & Dolomite Limestone & $12.8+-0.06$ & 3 & $12.72(\mathrm{G})$ \\
\hline
\end{tabular}

* determinations on several days, other determinations replicate

A Abbey (1983), G Govindaraju (1989)

Table 2. Non-carbonate carbon, $\mathrm{C}_{\mathrm{NONC}}$, in 14 international geological reference samples. $\mathrm{C}_{\mathrm{NONC}}$ determined after $\mathrm{HCl}$ treatment by infrared absorption method. $\mathrm{SD}=$ standard deviation. $\mathrm{N}=$ number of determinations.

\begin{tabular}{|c|c|c|c|c|}
\hline Sample & & $\begin{array}{c}\text { Mean }+-\mathrm{SD} \\
\% \mathrm{C}_{\mathrm{NONC}}\end{array}$ & $\mathrm{N}$ & $\begin{array}{c}\text { Literature } \\
\text { values } \\
\% \mathrm{C}_{\mathrm{NONC}}\end{array}$ \\
\hline SY-2 & Syenite & $0.01+-0.01$ & 3 & $0.03(\mathrm{~A})$ \\
\hline MRG-1 & Gabbro & $0.02+-0.01$ & 3 & $0.03(\mathrm{~A})$ \\
\hline SY-3 & Syenite & $0.03+-0.01$ & 3 & 0.03 (A) \\
\hline GXR-4 & Copper Mill Head & $0.04+-0.01$ & 3 & \\
\hline GXR-1 & Jasperoid & $0.05+-0.01$ & 3 & \\
\hline NBS-88a & Dolomite Limestone & $0.06+-0.02$ & 3 & \\
\hline \multirow[t]{2}{*}{ GXR-3 } & Fe-Mn-W-rich & & & \\
\hline & Hot Spring Deposit & $0.07+-0.01$ & 3 & \\
\hline GXR-6 & Soil & $0.10+-0.01$ & 3 & \\
\hline \multirow[t]{2}{*}{ ES $681-1$} & Iron Ore & $0.22+-0.02$ & $7 *$ & $0.33(\mathrm{~A})$ \\
\hline & & $0.22+-0.02 * *$ & 3 & \\
\hline SCo-1 & Cody Shale & $0.25+-0.01$ & 3 & $0.24(\mathrm{~A})$ \\
\hline GXR-5 & Soil & $0.83+-0.04$ & 3 & \\
\hline MAG-1 & Marine Mud & $1.61+-0.01$ & 3 & \\
\hline GXR-2 & Soil & $2.03+-0.05$ & 3 & \\
\hline SDO-1 & Devonian Ohio Shale & $9.65+-0.07$ & $7 *$ & $9.67(\mathrm{G})$ \\
\hline
\end{tabular}

* determinations on several days, other determinations replicate

** $\mathrm{V}_{2} \mathrm{O}_{5}$ as a flux by combustion
A Abbey (1983)
G Govindaraju (1989) 
Determination of total and non-carbonate carbon in rock samples by a method using infrared absorption 153

Table 3. Carbonate carbon, $\mathrm{CO}_{2}$, in 14 international geological reference samples. $\% \mathrm{CO}_{2}=\left(\% \mathrm{C}_{\mathrm{TOT}}-\% \mathrm{C}_{\mathrm{NONC}}\right) *$ 3.6641. The difference, $\% \mathrm{C}_{\mathrm{TOT}}-\% \mathrm{C}_{\mathrm{NONC}}$, is calculated from the results in Tables 1 and $2 . \mathrm{SD}=$ standard deviation.

\begin{tabular}{|c|c|c|c|c|}
\hline Sample & & $\begin{array}{c}\text { Mean }+-\mathrm{SD} \\
\% \mathrm{C}_{\mathrm{TOT}}-\% \mathrm{C}_{\mathrm{NONC}}\end{array}$ & $\begin{array}{c}\text { Mean }+-\mathrm{SD} \\
\% \mathrm{CO}_{2}\end{array}$ & $\begin{array}{c}\text { Literature } \\
\text { values } \\
\% \mathrm{CO}_{2} \\
\end{array}$ \\
\hline SY-2 & Syenite & $0.15+-0.02$ & $0.55+-0.09$ & $0.50(\mathrm{G})$ \\
\hline MRG-1 & Gabbro & $0.30+-0.01$ & $1.10+-0.02$ & $1.07(\mathrm{G})$ \\
\hline SY-3 & Syenite & $0.10+-0.01$ & $0.37+-0.02$ & $0.38(\mathrm{~A})$ \\
\hline GXR-4 & Copper Mill Head & $0.01+-0.01$ & $0.04+-0.02$ & \\
\hline GXR-1 & Jasperoid & $0.09+-0.02$ & $0.33+-0.06$ & \\
\hline NBS-88a & Dolomite Limestone & $12.7+-0.06$ & $46.5+-0.23$ & $46.61(\mathrm{G})$ \\
\hline \multirow[t]{2}{*}{ GXR-3 } & Fe-Mn-W-rich & & & \\
\hline & Hot Spring Deposit & $1.19+-0.02$ & $4.36+-0.06$ & \\
\hline GXR-6 & Soil & $0.07+-0.01$ & $0.26+-0.02$ & \\
\hline ES $681-1$ & Iron Ore & $1.47+-0.07$ & $5.39+-0.24$ & 5.4 (A) \\
\hline SCo-1 & Cody Shale & $0.72+-0.06$ & $2.64+-0.22$ & $2.75(\mathrm{~A})$ \\
\hline GXR-5 & Soil & $1.22+-0.07$ & $4.47+-0.27$ & \\
\hline MAG-1 & Marine Mud & $0.62+-0.02$ & $2.27+-0.06$ & \\
\hline GXR-2 & Soil & $0.75+-0.05$ & $2.75+-0.17$ & \\
\hline SDO-1 & Devonian Ohio Shale & $0.32+-0.06$ & $1.17+-0.21$ & $1.01(\mathrm{G})$ \\
\hline
\end{tabular}

A Abbey (1983)
G Govindaraju (1989)

Table 4. Total carbon, $\mathrm{C}_{\mathrm{TOT}}$, and non-carbonate carbon, $\mathrm{C}_{\mathrm{NONC}}$, in 13 in-house reference rock samples. $\mathrm{C}_{\mathrm{TOT}}$ determined by combustion and infrared absorption. $\mathrm{C}_{\mathrm{NONC}}$ determined after $\mathrm{HCl}$ treatment by infrared absorption method. $\mathrm{SD}=$ standard deviation. $\mathrm{N}=$ number of determinations.

\begin{tabular}{|c|c|c|c|c|c|}
\hline Sample & & $\begin{array}{c}\text { Mean }+ \text {-SD } \\
\% \mathrm{C}_{\text {TOт }}\end{array}$ & $\mathrm{N}$ & $\begin{array}{c}\text { Mean +-SD } \\
\% \mathrm{C}_{\mathrm{NONC}} \\
\end{array}$ & $\mathrm{N}$ \\
\hline RS 11 & Gabbro & $0.03+-0.01$ & 3 & $0.02+-0.02$ & 3 \\
\hline \multirow[t]{2}{*}{ RS 31} & Rapakivi & & & & \\
\hline & Granite & $0.01+-0.01$ & 3 & $0.01+-0.01$ & 3 \\
\hline RS 51 & Quartzite & $0.01+-0.00$ & 3 & $0.01+-0.01$ & 3 \\
\hline RS 61 & Trondhjemite & $0.02+-0.00$ & 3 & $0.00+-0.00$ & 3 \\
\hline RS 71 & Diabase & $0.01+-0.01$ & 3 & $0.00+-0.00$ & 3 \\
\hline RS 81 & Granite & $0.03+-0.01$ & 3 & $0.01+-0.01$ & 3 \\
\hline RS 91 & Phyllite & $0.45+-0.01$ & $23^{*}$ & $0.45+-0.02$ & $43^{*}$ \\
\hline RS 101 & Diorite & $0.04+-0.00$ & 3 & $0.02+-0.01$ & 3 \\
\hline RS 111 & Granite & $0.01+-0.01$ & 3 & $0.00+-0.00$ & 3 \\
\hline \multirow[t]{2}{*}{ RS 121} & Peridotic & & & & \\
\hline & komatiite & $0.08+-0.00$ & $23^{*}$ & $0.05+-0.01$ & 3 \\
\hline \multirow[t]{2}{*}{ RS 131} & Basaltic & & & & \\
\hline & komatiite & $0.71+-0.01$ & $23^{*}$ & $0.02+-0.01$ & 3 \\
\hline RS 211 & Serpentinite & $0.05+-0.01$ & 3 & $0.02+-0.01$ & 3 \\
\hline RS 212 & Serpentinite & $0.14+-0.01$ & $23^{*}$ & $0.02+-0.02$ & 3 \\
\hline
\end{tabular}

* determinations on several days, other determinations replicate

4-5). The results for $\mathrm{C}_{\mathrm{NONC}}$ and $\mathrm{CO}_{2}$ in 13 other rock samples also agreed well with the gravimetric methods (Tables 6-7).

The values of the replicate blank analysis of the total carbon were obtained by analyzing pure quartz ten times. The standard deviation (s) was $0.0037 \% \mathrm{C}$. The detection limit of the total carbon, defined as 3 times the standard deviation (3s) of the blank value, was $0.011 \% \mathrm{C}$.

The effective detection limit of the total car- 
Table 5. Carbonate carbon, $\mathrm{CO}_{2}$, in 13 in-house reference samples determined by infrared absorption method and by acid evolution - gravimetric method. $\% \mathrm{CO}_{2}=\left(\% \mathrm{C}_{\mathrm{TOT}}-\% \mathrm{C}_{\mathrm{NONC}}\right) * 3.6641$. The difference, $\% \mathrm{C}_{\mathrm{TOT}}-\% \mathrm{C}_{\mathrm{NONC}}$, is calculated from the results in Table $4 . \mathrm{SD}=$ standard deviation.

\begin{tabular}{|c|c|c|c|c|c|}
\hline \multirow[t]{2}{*}{ Sample } & & \multicolumn{2}{|c|}{ Infrared absorption method } & \multicolumn{2}{|c|}{$\begin{array}{c}\text { Acid ev.-gravim. } \\
\text { method }\end{array}$} \\
\hline & & \multirow{2}{*}{$\begin{array}{c}\text { Mean }+-\mathrm{SD} \\
\% \mathrm{C}_{\mathrm{TOT}}-\% \mathrm{C}_{\mathrm{NONC}} \\
0.01+-0.01\end{array}$} & $\begin{array}{c}\text { Mean }+-\mathrm{SD} \\
\% \mathrm{CO}_{2}\end{array}$ & $\% \mathrm{CO}_{2}$ & $\% \mathrm{CO}_{2}$ \\
\hline RS 11 & Gabbro & & $0.04+-0.04$ & 0.08 & 0.08 \\
\hline \multirow[t]{2}{*}{ RS 31} & Rapakivi & & & & \\
\hline & Granite & $0.00+-0.01$ & $0.00+-0.02$ & 0.03 & 0.03 \\
\hline RS 51 & Quartzite & $0.00+-0.01$ & $0.00+-0.02$ & 0.00 & 0.00 \\
\hline RS 61 & Trondhjemite & $0.02+-0.01$ & $0.07+-0.02$ & 0.05 & 0.05 \\
\hline RS 71 & Diabase & $0.01+-0.01$ & $0.04+-0.04$ & 0.07 & 0.03 \\
\hline RS 81 & Granite & $0.02+-0.02$ & $0.07+-0.08$ & 0.05 & 0.05 \\
\hline RS 91 & Fyllite & $0.00+-0.01$ & $0.00+-0.03$ & 0.00 & 0.00 \\
\hline RS 101 & Diorite & $0.02+-0.01$ & $0.07+-0.02$ & 0.12 & 0.11 \\
\hline RS 111 & Granite & $0.01+-0.01$ & $0.04+-0.02$ & 0.02 & 0.02 \\
\hline \multirow[t]{2}{*}{ RS 121} & Peridotitic & & & & \\
\hline & komatiite & $0.03+-0.01$ & $0.11+-0.04$ & 0.06 & 0.05 \\
\hline \multirow[t]{2}{*}{ RS 131} & Basaltic & & & & \\
\hline & komatiite & $0.69+-0.01$ & $2.53+-0.04$ & 2.71 & 2.68 \\
\hline RS 211 & Serpentinite & $0.03+-0.01$ & $0.11+-0.03$ & 0.14 & 0.13 \\
\hline \multirow[t]{3}{*}{ RS 212} & Serpentinite & $0.12+-0.01$ & $0.44+-0.04$ & 0.46 & 0.49 \\
\hline & & & & 0.50 & 0.50 \\
\hline & & & & 0.51 & \\
\hline
\end{tabular}

Table 6. Total carbon, $\mathrm{C}_{\mathrm{TOT}}$, and non-carbonate carbon, $\mathrm{C}_{\mathrm{NONC}}$, in 13 rock samples. $\mathrm{C}_{\mathrm{TOT}}$ determined by infrared absorption method. $\mathrm{C}_{\mathrm{NONC}}$ determined after $\mathrm{HCl}$ treatment by infrared absorption method and by gravimetric method. $\mathrm{SD}=$ standard deviation.

\begin{tabular}{|c|c|c|c|}
\hline \multirow[t]{2}{*}{ Sample } & \multicolumn{2}{|c|}{ Infrared absorption method } & \multirow{2}{*}{$\begin{array}{l}\text { Gravimetric } \\
\text { method** } \\
\% \mathrm{C}_{\mathrm{NONC}}\end{array}$} \\
\hline & $\begin{array}{c}\text { Mean }+-\mathrm{SD}^{*} \\
\% \mathrm{C}_{\mathrm{TOT}}\end{array}$ & $\begin{array}{c}\text { Mean }+-\mathrm{SD}^{*} \\
\% \mathrm{C}_{\mathrm{NONC}}\end{array}$ & \\
\hline 1. $\mathrm{Rb} 21 / 75$ & $0.25+-0.02$ & $0.03+-0.02$ & 0.08 \\
\hline 2. $\mathrm{Rb} 104 / 74$ & $0.64+-0.05$ & $0.62+-0.04$ & 0.52 \\
\hline 3. $\mathrm{Rb} 102 / 74$ & $0.70+-0.01$ & $0.24+-0.01$ & 0.23 \\
\hline 4. $\mathrm{Rb} 103 / 74$ & $2.06+-0.02$ & $1.85+-0.06$ & 1.80 \\
\hline 5. $\mathrm{Rb} 63 / 74$ & $4.96+-0.02$ & $0.67+-0.02$ & 0.63 \\
\hline 6. $\mathrm{Rb} 62 / 74$ & $5.43+-0.04$ & $0.44+-0.01$ & 0.47 \\
\hline 7. $\mathrm{Rb} 61 / 74$ & $5.75+-0.03$ & $1.01+-0.01$ & 1.06 \\
\hline 8. Rb $98 / 74$ & $5.99+-0.06$ & $3.99+-0.02$ & 4.03 \\
\hline 9. $\mathrm{Rb} 64 / 74$ & $6.05+-0.06$ & $0.29+-0.05$ & 0.26 \\
\hline 10. Rb $54 / 74$ & $6.20+-0.02$ & $0.79+-0.03$ & 0.76 \\
\hline 11. $\mathrm{Ra} 601 / 76$ & $6.58+-0.02$ & $0.30+-0.02$ & 0.31 \\
\hline 12. Rb $107 / 74$ & $6.83+-0.02$ & $0.63+-0.02$ & 0.65 \\
\hline 13. Ra $600 / 76$ & $6.83+-0.02$ & $1.49+-0.01$ & 1.31 \\
\hline
\end{tabular}

* replicate determinations

** Laajoki and Saikkonen 1977

1. Fe-silicate (grunerite)-magnetite rock (slightly weathered). Iso Vuorijärvi iron formation.

2. Amphibole-magnetite-chert mesoband, Pääkkö.

3. Chert Mesoband, Pääkkö.

4. Magnetite-amphibole-chert mesoband, Pääkkö.

5. Quartz-siderite-banded rock. Pääkkö iron formation.

6. Quartz-siderite-banded rock. Iso Vuorijärvi iron formation.

7. Quartz-siderite-banded rock. Pääkkö iron formation.

8. Spessartite-bearing iron-rich black schist. Seppola iron formation.

9. Quartz-siderite-banded rock. Iso Vuorijärvi iron formation.

10. Quartz-siderite-banded rock. Pääkkö iron formation.

11. Siderite rock. Pääkkö iron formation.

12. Phosphorite-banded siderite rock. Pääkkö iron formation.

13. Laminated quartz-sideritə rock. Pääkkö iron formation. 
Table 7. Carbonate carbon, $\mathrm{CO}_{2}$, in 13 rock samples determined by infrared absorption method and by acid evolution gravimetric method. $\% \mathrm{CO}_{2}=\left(\% \mathrm{C}_{\mathrm{TOT}}-\% \mathrm{C}_{\mathrm{NONC}}\right) * 3.6641$. The difference, $\% \mathrm{C}_{\mathrm{TOT}}-\%_{0} \mathrm{C}_{\mathrm{NONC}}$, is calculated from the results in Table $6 . \mathrm{SD}=$ standard deviation.

\begin{tabular}{|c|c|c|c|}
\hline \multirow[t]{2}{*}{ Sample } & \multicolumn{2}{|c|}{ Infrared absorption method } & \multirow{2}{*}{$\begin{array}{c}\text { Acid ev.-gravim. } \\
\text { method** } \\
\% \mathrm{CO}_{2}\end{array}$} \\
\hline & $\begin{array}{c}\text { Mean }+-\mathrm{SD}^{*} \\
\% \mathrm{C}_{\mathrm{TOT}}-\% \mathrm{C}_{\mathrm{NONC}}\end{array}$ & $\begin{array}{c}\text { Mean }+-\mathrm{SD}^{*} \\
\% \mathrm{CO}_{2}\end{array}$ & \\
\hline 1. $\mathrm{Rb} 21 / 75$ & $0.22+-0.03$ & $0.81+-0.09$ & 0.64 \\
\hline 2. $\mathrm{Rb} 104 / 74$ & $0.02+-0.01$ & $0.07+-0.04$ & 0.10 \\
\hline 3. $\mathrm{Rb} 102 / 74$ & $0.46+-0.01$ & $1.68+-0.02$ & 1.59 \\
\hline 4. $\mathrm{Rb} 103 / 74$ & $0.21+-0.08$ & $0.77+-0.28$ & 0.66 \\
\hline 5. $\mathrm{Rb} 63 / 74$ & $4.29+-0.03$ & $15.7+-0.10$ & 15.6 \\
\hline 6. $\mathrm{Rb} 62 / 74$ & $4.99+-0.03$ & $18.3+-0.10$ & 18.5 \\
\hline 7. $\mathrm{Rb} 61 / 74$ & $4.74+-0.02$ & $17.4+-0.07$ & 17.7 \\
\hline 8. Rb $98 / 74$ & $2.00+-0.08$ & $7.33+-0.27$ & 7.48 \\
\hline 9. $\mathrm{Rb} 64 / 74$ & $5.76+-0.10$ & $21.1+-0.35$ & 20.9 \\
\hline 10. Rb $54 / 74$ & $5.41+-0.01$ & $19.8+-0.03$ & 20.1 \\
\hline 11. Ra $601 / 74$ & $6.28+-0.02$ & $23.0+-0.07$ & 22.6 \\
\hline 12. $\mathrm{Rb} 107 / 74$ & $6.20+-0.02$ & $22.7+-0.06$ & 22.5 \\
\hline 13. Ra $600 / 76$ & $5.34+-0.03$ & $19.6+-0.10$ & 19.9 \\
\hline
\end{tabular}

* 3 replicate determinations

** Laajoki and Saikkonen 1977

bon using a sample weight of $0.5-1.0 \mathrm{~g}$ was $0.01-0.02 \% \mathrm{C}$. The standard deviation (s) of the non-carbonate carbon was $0.0058 \% \mathrm{C}$ and the detection limit ( $3 \mathrm{~s}$ ) was $0.017 \% \mathrm{C}$. The effective detection limit of the non-carbonate carbon using a sample weight of $0.5-1.0 \mathrm{~g}$ was approximately $0.02 \% \mathrm{C}$.

\section{Discussion}

Errors arising from the incomplete oxidation of the organic carbon to carbon dioxide by combustion can usually be eliminated by using an oxidizing flux such as vanadium pentoxide in the combustion step. The discrepancy between our value and the published value for the noncarbonate carbon of sample ES 681-1 (Table 2) was not removed, however, when we made a second determination with $\mathrm{V}_{2} \mathrm{O}_{5}$ added as flux. Perhaps volatile and soluble components of the organic carbon were lost during the $\mathrm{HCl}$ treatment; for ancient sediments the loss is low, but for recent sediments it may be significant (Durand \& Nicaise 1980).
We also observed that too high a drying temperature led to the loss of organic carbon from some samples (also noted by Durand \& Nicaise). The samples SDO-1 $\left(\mathrm{C}_{\mathrm{NONC}} 9.65 \%\right)$, GXR-2 $\left(\mathrm{C}_{\text {NONC }} 2.03 \%\right)$ and GXR-5 $\left(\mathrm{C}_{\text {NONC }} 0.83 \%\right)$ were dried at $200^{\circ} \mathrm{C}$ overnight and the results were low: $6.15 \%, 1.59 \%$ and $0.63 \%$, respectively. The subtraction of one large number from another is liable to cause error in the calculated $\mathrm{CO}_{2}$ when samples with high non-carbonate carbon are analyzed. The sample SDO-1 is an example (Table 3).

Once the CR-12 instrument is set up and has stabilized the operation is easy. The method is simple and rapid. The measurements of the carbon content for most samples required only a few minutes: about 70 determinations of the total carbon and 40 determinations of the non-carbonate carbon can be made by one analyst daily, compared with 10 determinations with the gravimetric method. The instrument should be cleaned of dust after about 100 determinations of the noncarbonate carbon, and after about 500 determinations of the total carbon. This requires several hours. 
Calibration is required and international reference samples or in-house reference samples need to be analyzed daily to confirm the accuracy and stability of the instrument. The method is suitable for determining the carbon content in ancient sediments and in igneous and metamorphic rock samples containing more than $0.01 \%$ C. A sample size of $0.5-1.0 \mathrm{~g}$ is recommended.

Acknowledgement. We wish to thank Mr. Juha Karhu, Dr. Kari Kinnunen and Mr. Esko Kontas for critically reading the manuscript. We are also indebted to Mrs. Kathleen Ahonen for correcting our english.

\section{References}

Abbey, S., 1983. Studies in "Standard Samples» of Silicate Rocks and Minerals, 1969-1982. Geol. Surv. of Canada, Paper 83-15.

Andraues, F. F. \& Gibson, E. K., 1979. Release and Analysis of Gases from Geological Samples. Amer. Mineral. 64, 453-463.

Betelev, N. P., \& Kudachkin, B. I., 1988. Comparative Measurements of $\mathrm{C}_{\text {org }}$ and $\mathrm{CO}_{2}$ Contents of Carbonates with Various Methods. Lithol. and Min. Resources 23, $102-107$.

Bouvier, J. L. \& Abbey, S., 1980. Simultaneous Determination of Water, Carbon Dioxide and Sulfur in Rocks by Volatilization and Non-dispersive Infrared Absorptiometry. Can. J. of Spectr. 25, 126-132.

Cahill, R. A. \& Autrey, A. D., 1988. Total and Inorganic Carbon Content of Eighteen National Bureau of Standards and Four Canadian Certified Reference Materials. Geostand. Newslett. 12, 39-42.

Chan, C. C. Y., 1986. Determination of Carbonate Carbon in 41 International Geochemical Reference Samples by Coulometric Method. Geostand. Newslett. 10, 131-134.

Charles, M. J. \& Simmons, M. S., 1986. Methods for Determination of Carbon in Soils and Sediments. A Review. Analyst 3, 385-390.

Durand, B. \& Nicaise, G., 1980. Procedures for Kerogen Isolation. Kerogen Insoluble Organic Matter from Sedimentary Rocks. Ed. B. Durand, 35-53.

Engleman, E. E., Jackson, L. L. \& Norton, D. R., 1985. Determination of Carbonate Carbon in Geological Materials by Coulometric Titration. Chem. Geol. 53, 125-128.

Govindaraju, K., 1989. 1989 Compilation of Working Values and Sample Description for 272 Geostandards. Geostand. Newslett. 13, Special Issue.

Gongalyuk, N. G., Kuzmina, G. N., Romanova, L. V. \& Tverdova, R. A., 1986. Spectrochemical Determination of Organic Carbon in Phosphate Rock. Industr. Lab. 52, $146-149$.

Hillebrand, W.F.,Lundell,G.E.F.,Bright,H.A. and Hoffman,J.I., 1953. Applied Inorganic Analysis, 2nd ed., New york: John Wiley and Sons, 768-772.

Huffman, E. W. D. Jr., 1977. Performance of a New Automatic Carbon Dioxide Coulometer. Microchem. Jour. 22, 567-573.

Johnson, W. M. and Maxwell, J. A., 1981. Rock and Mineral Analysis, 2nd ed., New York: John Wiley and Sons, $123-135$.

Krom, M. D. \& Berner, R. A., 1983. A Rapid Method for the Determination of Organic and Carbonate Carbon in Geological Samples. Jour. Sed. Petrol. 53, 660-663.

Laajoki, K. \& Saikkonen, R., 1977. On the Geology and Geochemistry of the Precambrian Iron Formation in Väyrylänkylä, South Puolanka Area, Finland. Geol. Surv. Finland, Bull. 292.

Leventhal J. S. and Shaw V. E., 1980. Organic Matter in Appalacian Devonian Black Shale: I. Comparison of Techniques to Measure Organic Carbon; II. Short Range Organic Carbon Content Variations. J. Sed. Petrol. 50, $77-81$.

Maxwell. J. A., 1968. Rock and Mineral Analysis. Interscience, New York. 217-224.

Riddle, A. T. \& Talerico, F., 1978. Determination of Carbon Dioxide in Rock Analysis by Non-aqueous Titration. Chem. Geol. 21, 351-357.

Roedder, E., 1984. Fluid Inclusions. Reviews in Mineralogy 12, Mineralog. Soc. of Amer., Washington, D. C., 644.

Schofield, T. G., Gladney, E. S., Miera, F. R. Jr.\& Trujillo,P. E., 1980. Comparative Determination of Carbon, Nitrogen and Hydrogen in Environmental Standard Reference Materials by Instrumental Combustion Analysis and Thermal Neutron Capture Gamma-ray Spectrometry. Anal. Lett. 13, 75-83.

Terashima, S., 1988. Determination of Total Carbon and Sulfur in Fifty-two Geochemical Reference Samples by Combustion and Infrared Absorption Spectrometry. Geostand. Newslett. 12, 249-252.

Volborth, A., 1969. Elemental Analysis in Geochemistry. Elsevier Publishing Company, Amsterdam, 113-118. Wedepohl, K. H., 1978. Handbook of Geochemistry. Vol. 2/1. Wurzburg: Springer-Verlag, 6-D-1.

Received May 28, 1990

Revision accept August 17, 1990 